\title{
Pengaruh Pemberian Air Rebusan Akar Ilalang (Imperata cylindrica) Terhadap Stamina Mencit Jantan (Mus musculus)
}

\author{
The Influence of Ilalang Root Drinking Water (Imperata cylindrica) \\ Against Stamina Chicking A Heart (Mus musculus)
}

\author{
Dito Dwi Sumarsono $^{1 *}$, Yohanes Edy Gunawan ${ }^{2}$, Adventus Panda ${ }^{2}$ \\ ${ }^{1}$ Program Studi Pendidikan Biologi, Jurusan Pend. MIPA, FKIP, Universitas Palangka Raya \\ ${ }^{2}$ Program Studi Biologi, FMIPA, Universitas Palangka Raya \\ *Alamat email: ditodwisumarsono@gmail.com
}

\begin{abstract}
Abstrak - Ilalang (Imperata cylindrica) termasuk famili Poaceae. Akar tumbuhan ini oleh sebagian masyarakat di Kalimantan Tengah digunakan untuk meningkatkan stamina. Masyarakat yang memanfaatkan air rebusan akar ilalang agar tidak mudah lelah. Tujuan penelitian ini untuk mengetahui khasiat air rebusan ilalang terhadap stamina mencit Swiss Webster jantan. Penelitian ini dilakukan dengan acar menghitung frekuensi tunggangan mencit jantan selama satu jam. Penelitian ini merupakan penelitian eksperimen dengan menggunakan Rancangan Acak Lengkap $(R A L)$ dengan 4 perlakuan dan masing-masing perlakuan memiliki 6 kali ulangan. Masing-masing perlakuan menggunakan akuades, minuman berenergi $13 \mathrm{~mL} / \mathrm{kg} \mathrm{BB}$, Rebusan air akar ilalang $9 \mathrm{~mL} / \mathrm{kg} B B$, dan rebusan air akar ilalang $18 \mathrm{~mL} / \mathrm{kg} \mathrm{BB}$. Analisis data menggunakan aplikasi spss PASW versi 18 dengan uji ANOVA 1 arah (one way anova) dan uji lanjut Duncan's Multiple Range Test (DMRT) dengan tingkat kepercayaan 95\%. Hasil penelitian menunjukkan air rebusan akar ilalang meningkatkan stamina mencit jantan secara nyata $\left(F_{\text {hit }} 11,51>F_{\text {tab }} 3,10\right)$. Hasil uji lanjut menggunakan DMRT menunjukkan pemberian air rebusan akar ilalang $18 \mathrm{~mL} / \mathrm{kg} \mathrm{BB} \mathrm{memiliki} \mathrm{rata-}$ rata frekuensi kawin tertinggi 47,50 kali dibandingkan dengan tiga kelompok perlakuan lainnya. Kesimpulan; air rebusan akar ilalang meningkatkan stamina mencit Swiss Webster jantan.
\end{abstract}

Kata Kunci: imperata cylindrica, stamina, uji kawin

\begin{abstract}
Ilalang (Imperata cylindrica) belongs to the family Poaceae. The roots of this plant are used by many people of Central Kalimantan to increase stamina. People who use the grass root decoction to avoid fatigue. The aims of this study was to determine the efficacy of edurance of male Swiss Webster mice. This research was conducted by pickling to calculate the frequency of mounts of male mice for one hour. This research is an experimental study using a completely randomized design (CRD) with 4 treatments and each treatment has 6 replications. Each treatment used distilled water, energy drinks $13 \mathrm{~mL} / \mathrm{kg} \mathrm{BW}$, boiled root water water $9 \mathrm{~mL} / \mathrm{kg}$ $B W$, and boiled root water water $18 \mathrm{~mL} / \mathrm{kg} B W$. Data analysis used the PASW version 18 application of SPSS with one way ANOVA test and Duncan's Multiple Range Test (DMRT) with 95\% confidence level. The results showed that the boiled root of the grass has significantly increased male stamina (Fhit 11.51> Ftab 3.10). The results of further tests using DMRT showed that $18 \mathrm{~mL} / \mathrm{kg} B W$ grass boiled water had the highest mating frequency of 47.50 times compared to the other three treatment groups. Conclusion; boiled water of Imperata cylindrica roots increases the stamina of male Swiss Webster mice.
\end{abstract}

Keyword: grass roots, energy, edurance.

\author{
๑) 2019 Jurnal Jejaring Matematika dan Sains. This work is licensed under a CC BY-NC 4.0 \\ Sejarah Artikel \\ Diterima : 16 November 2019 \\ Disetujui : 24 Desember 2019
}

\section{PENDAHULUAN}

Tumbuhan telah dimanfaatkan untuk memenuhi kebutuhan pangan, obat-obatan, kosmetik dan bahan pestisida [1]. Obat-obatan dan jamu-jamuan, diyakini sebagai obat untuk mengobati berbagai penyakit. Sekitar 200 tanaman telah digunakan sebagai sumber bahan industri obat modern. Pengetahuan mengenai tumbuhan obat memiliki karakteristik berbeda-beda pada suatu wilayah. Pengetahuan tersebut biasanya merupakan warisan secara turun-menurun [2].

Ilalang dikenal sebagai tumbuhan gulma yang termasuk famili rumput-ramputan (Poaceae) [3]. Beberapa pustaka pengobatan tradisional dapat dijumpai pemanfaatan Akar ilalang digunakan untuk mengobati 
darah tinggi, dan obat penyakit dalam [4], sakit pinggang, sakit kuning [5], dan obat muntah darah, misisan, kencing nanah, hepatitis akum, campak, dan radang ginjal [6].

Sebagian masyarakat di Kalimantan Tengah memanfaatkan akar ilalang untuk meningkatkan stamina (tonik). Masyarakat memanfaatkan akar ilalang saat mememerlukan waktu kerja yang lebih lama dan atau memeerlukan energi lebih banyak. Pengguna merasa tidak mudah lelah ketika menggunakan seduhan akar ilalang (wawancara pribadi). Meskipun telah dirasakan khasiatnya, namun kajian ilmiah khasiatnya belum ditemukan.

Uji aktivitas kawin mencit jantan merupakan salah satu teknik untuk uji stamina. Uji aktivitas dilakukan dengan menghitung frekuensi tunggangan mencit jantan selama satu jam. Mencit jantan membutuhkan banyak energi untuk melakukan aktivitas kawin. Penggunaan hewan uji sebagai model dapat menghindari biasnya data yang muncul dari faktor sugesti dan subjektivitas penggunaan. Berdasarkan alasan tersebut akan dilakukan penelitian: Pengaruh Pemberian Rebusan Air Akar Ilalang (Imperata cylindrica) Terhadap Stamina Mencit Jantan (Mus musculus) Swiss Webster Jantan.

\section{METODE PENELITIAN}

Penelitian menggunakan metode deskriptif eksperimental. Penelitian menggunakan hewan uji mencit jantan dibagi secara acak menjadi empat kelompok penelitian kelompok kontrol negatif, kontrol positif minuman berenergi dosis $13 \mathrm{~mL} / \mathrm{kg} \mathrm{BB}$, perlakuan rebusan air akar Ilalang dengan dosis $9 \mathrm{~mL} / \mathrm{kg}$ $\mathrm{BB}$, dan perlakuan menggukan rebusan air akar Ilalang dengan dosis $18 \mathrm{~mL} / \mathrm{kg} \quad \mathrm{BB}$ masing-masing menggunakan enam ulangan, selama tujuh hari. Pengumpulan data dilakukan selama tujuh hari. Data yang dikumpulkan meliputi frekuensi tunggangan selama 1 jam. Data yang didapat kemudian ditabulasikan. Data yang diperoleh berupa frekuensi kawin pada mencit jantan yang akan dianalisis menggunakan analisis variansi dengan software SPSS 18. Hasil analisis, di uji lanjut menggunakan DMRT.

\section{HASIL PENELITIAN DAN PEMBAHASAN}

Hasil penelitian yang disajikan pada penelitian ini berupa frekuensi kawin setiap kelonpok perlakuan yang dianalisis menggunakan analisis varians dan dilanjutkan dengan uji lanjut. Data penunjang berupa perubahan berat badan hewan uji.

Pemberian air rebusan akar ilalang terhadap stamina mencit jantan selama pengamatan 7 hari dapat dilihat pada Gambar 1. Jumlah Rata-rata frekuensi tunggangan (kawin) pada perlakuan menggunakan aquades sebanyak 25 kali, pada perlakuan menggunakan minuman berenergi sebanyak 17 kali, pada perlakuan air rebusan akar ilalang $9 \mathrm{~mL} / \mathrm{kg}$ BB sebanyak $29 \mathrm{kali}$, dan pada perlakuan air rebusan akar ilalang $18 \mathrm{~mL} / \mathrm{kg}$ BB sebesar 47 kali.

Hasil analisis varians menunjukkan pemberian air rebusan akar ilalang meningkatkan frekuensi kawin mencit jantan dimana Fhit 11,51 $\geq$ Ftab 3,10 (Tabel 1). Hasil uji lanjut DMRT menunjukkan tidak ada perlakuan yang paling berpengaruh tetapi pada kelompok perlakuan 2 menggunakan air rebusan akar ilalang 18 $\mathrm{mL} / \mathrm{kg}$ BB direkomendasikan karena memiliki rata-rata frekuensi kawin tertinggi 47,50 kali dibandingkan dengan tiga kelompok perlakuan lainnya (Tabel 2).

Hasil uji menunjukkan frekuensi kawin disajikan pada Gambar 1. Tampak pada gambar tersebut frekuensi kawin terendah adalah pada kelompok perlakuan menggunakan minum berenergi. Kemudian secara berurutan kontrol negatif, perlakuan P1 dan Perlakuan P2. Berdasarkan data tersebut tampak pemberian rebusan air akar ilalang meningkatkan rerata frekuensi kawin mencit jantan seiring dengan dosis yang digunakan.

Hasil pengamatan rerata berat badan menunjukkan, pemberian rebusan air akar ilalang tidak meningkatkan rerata berat badan dibandingkan kelompok kontrol (Gambar 2). Hasil ini berbeda dengan pemberian minuman berbenergi yang meningkatkan berat badan mencit jantan kelompok kontrol positif. menunjukkan perlakuan menggunakan minuman berenergi memiliki rata-rata kenaikan berat badan paling tinggi yaitu 33 gram sedangkan aquades, rebusan akar ilalang $9 \mathrm{~mL} / \mathrm{kg}$ $\mathrm{BB}$ dan air rebusan ilalang $18 \mathrm{~mL} / \mathrm{kg}$ BB hanya 31 gram.

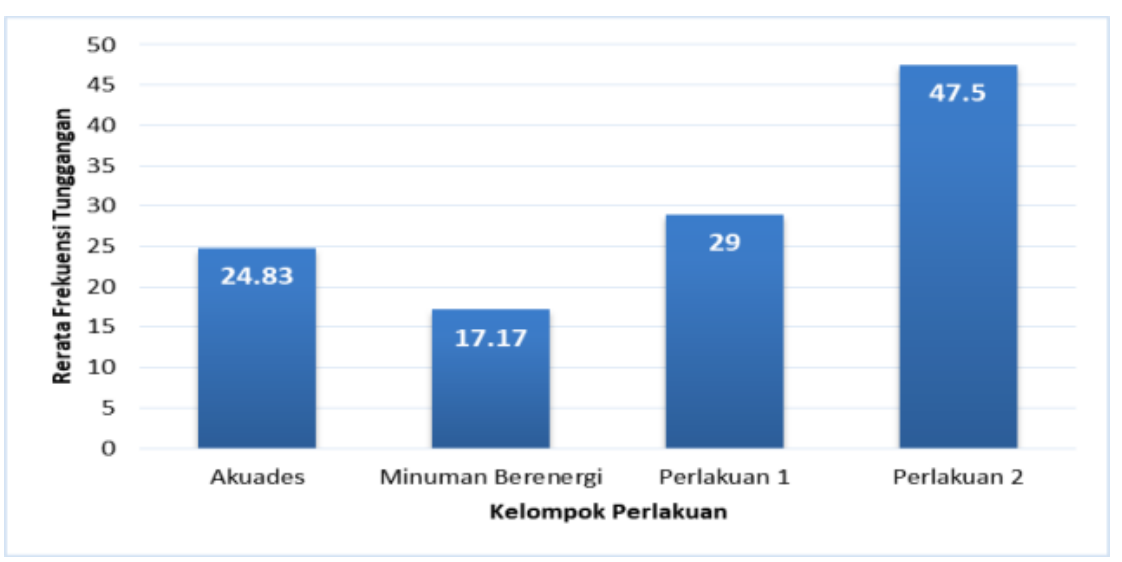

Gambar 1. Grafik Jumlah Rata-rata frekuensi tunggangan (kawin) selama 7 hari

Keterangan: (Akuades), (Minuman berenergi), (P1air rebusan akar ilalang $9 \mathrm{~mL} / \mathrm{kg} \mathrm{BB}$ ), (P2 air rebusan akar ilalang $18 \mathrm{~mL} / \mathrm{kg} \mathrm{BB}$ ) 


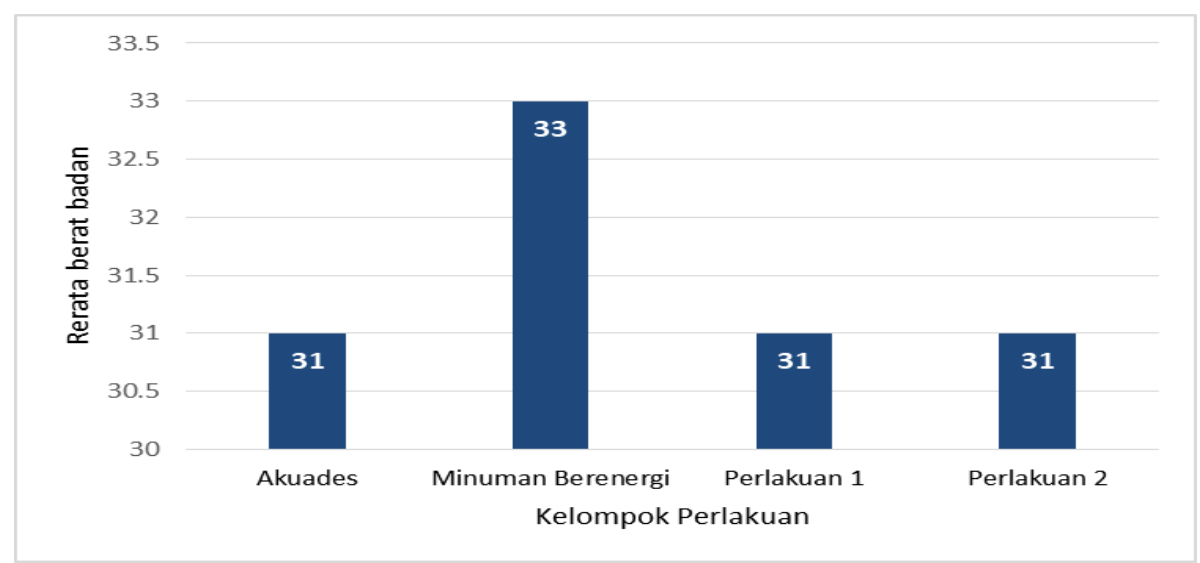

Gambar 2. Grafik rata-rata berat badan mencit jantan selama 7 hari

Keterangan: (Akuades), (Minuman berenergi) (P1air rebusan akar ilalang $9 \mathrm{~mL} / \mathrm{kg} \mathrm{BB}),(\mathrm{P} 2$ air rebusan akar ilalang $18 \mathrm{~mL} / \mathrm{kg} \mathrm{BB}$ )

Berdasarkan anova pada Tabel 1, tampak bahwa pemberian rebusan air akar ilalang berpengaruh terhadap stamina mencit jantan secara nyata pada taraf signifikasi 5\% ( $\left.\mathrm{F}_{\text {hit }} 11,51>\mathrm{F}_{\text {tab }} 3,10\right)$ maka dari itu $\mathrm{H}_{1}$ diterima. Berdasarkan hasil anova diatas, maka dilakukan uji lanjut menggunakan uji DMRT untuk mengetahui takaran dosis terbaik. Hasil uji lanjut menunjukkan tidak ada perlakuan yang paling berpengaruh tetapi pada kelompok perlakuan 2 menggunakan air rebusan akar ilalang $18 \mathrm{~mL} / \mathrm{kg} \mathrm{BB}$ paling direkomendasikan karena memiliki rata-rata frekuensi kawin tertinggi 47,50 kali dibandingkan dengan tiga kelompok perlakuan lainnya.

Tabel 1. Hasil Anova Banyaknya Frekuensi Tunggangan (Kawin) Mencit Jantan Selama 7 Hari.

\begin{tabular}{cccccc}
\hline $\begin{array}{c}\text { Sumber } \\
\text { Keragaman }\end{array}$ & $\begin{array}{c}\text { Jumlah } \\
\text { Kuadrat }\end{array}$ & $\begin{array}{c}\text { Derajat } \\
\text { Bebas }\end{array}$ & $\begin{array}{c}\text { Kuadrat } \\
\text { Tengah }\end{array}$ & F hitung & \multirow{2}{*}{ F5\% } \\
\hline Perlakuan & 2988,46 & 3,00 & 996,15 & 11,51 & 3,10 \\
Galat & 1731,17 & 20,00 & 86,56 & & \\
Total & 4719,63 & 23,00 & & & \\
\hline
\end{tabular}

Tabel 2. Hasil uji DMRT efek rebusan akar ilalang terhadap frekuensi kawin mencit Swiss Webster jantan.

Duncan $^{\mathrm{a}}$

\begin{tabular}{|c|c|c|c|c|}
\hline \multirow{2}{*}{ Perlakuan } & \multirow{2}{*}{$\mathrm{N}$} & \multicolumn{3}{|c|}{ Subset for alpha $=0.05$} \\
\cline { 3 - 5 } & & 1 & 2 & 3 \\
\hline 2 & 6 & 17,17 & & \\
& & & & \\
3 & 6 & 24,83 & 24,83 & \\
4 & 6 & & 29,00 & \\
Sig. & 6 & & & 47,50 \\
\end{tabular}


Rebusan air akar ilalang telah digunakan secara empiris meningkatkan stamina oleh sebagian masyarakat di Kalimantan Tengah. Hasil penelitian menunjukkan bawah rebusan air akar ilalang mampu meningkatkan stamina hewan uji secara nyata. Hasil ini menunjukkan rebusan air akar ilalang, dapat meningkatkan stamina seperti halnya minuman berenergi. Rebusan air akar ilalang digunakan oleh penduduk disaat melakukan pekerjaan yang memerlukan waktu lebih lama atau intensitasnya tinggi. Pola kerja aktifitas yang semakin meningkat membutuhkan tenaga yang lebih banyak, sehingga dapat menyebabkan kelelahan, karena itu kebutuhan akan minuman berenergi menjadi meningkat.

Uji aktivitas kawin mencit jantan merupakan salah satu teknik untuk uji stamina, dimana prilaku kawin mencit membutuhkan stamina yang lebih untuk melakukan aktivitas kawin dengan betinanya. Hasil penelitian ini menunjukkan penggunaan kelompok kontrol negatif dengan perlakuan akuades frekuensi kawinnya 24 kali, sedangkan kontrol positif dengan perlakuan menggunakan minuman berenergi memiliki frekuensi kawin 17 kali. Kelompok perlakuan menggunakan rebusan air akar ilalang meningkatkan stamina mencit dibandingkan dengan kedua kontrol tersebut. Hal ini tercermin dari meningkatnya frekuensi kawin kelompok hewan uji perlakuan dengan rebusan air akar alang-alang. Efek pemberian rebusan air akar ilalang $9 \mathrm{~mL} / \mathrm{kg}$ BB rata-rata frekuensi kawin $29 \mathrm{kali}$, sedangkan pada dosis $18 \mathrm{~mL} / \mathrm{kg}$ BB frekuensi kawinnya meningkat hingga hingga 47 kali. Hasil uji lanjut menunjukkan tidak ada perlakuan yang paling berpengaruh tetapi pada kelompok perlakuan 2 menggunakan air rebusan akar ilalang $18 \mathrm{~mL} / \mathrm{kg}$ BB paling direkomendasikan karena memiliki rata-rata frekuensi kawin tertinggi 47,50 kali dibandingkan dengan tiga kelompok perlakuan lainnya.

Hasil yang serupa ditunjukkan [7] mengungkapkan pemberian ramuan cabe jawa pegagan, dan temu lawak pada mencit yang menunjukan aktivitas tunggangan (kawin) pada mencit meningkat seiring peningkatan pemberian dosis ramuan cabe jawa.

Hasil penelitian pengaruh pemberian rebusan air akar ilalang terhadap stamina mencit jantan mengungkapkan, rebusan air akar ilalang tersebut mampu meningkatkan stamina hewan, seperti yang diungkapkan narasumber. Hal ini diduga dikarenakan adanya kandungan senyawa metabolit sekunder seperti flavonoid jenis quersetin yang bertindak sebagai tonikum yang memberikan efek tonik, sebagai penambahan stamina mencit jantan [8].

Kelompok senyawa quersetin diduga memiliki efek tonikum dengan mekanisme kerja antagonis dengan reseptor adenosin [9]. Adenosin pada otak befungsi melindungi otak dengan menekan aktivitas saraf dan meningkatkan aliran darah pada otot. Konsentrasi adenosin pada otak dijaga agar tetap dalam jumlah yang seimbang, karena itu secara alami tubuh akan mengirimkan sinyal "lelah" jika kadar adenosin meningkat dalam jumlah banyak dan berikatan dengan reseptor adenosin.

Peningkatan flavonoid golongan quersetin berlebih menyebabkan terjadinya ikatan dengan reseptor adenosin. Ini menyebabkan otak terus mengirimkan sinyal untuk meningkatkan aliran darah ke otot dan jantung, serta memacu produksi hormon adrenalin. Akibatnya tekanan darah meningkat, demikian juga sekresi asam lambung, dan aktifitas otot. Hal ini disertai dengan perangsangan hati untuk melepaskan glukosa pada aliran darah untuk menghasilkan energi ekstra. Akibatnya tubuh akan terasa fit dan bugar.

Tonikum adalah zat yang digunakan untuk mengembalikan kondisi normal jaringan atau untuk merangsang nafsu makan. Hal ini berguna untuk mengembalikan tenaga yang hilang, memulihkan stamina, melancarkan peredaran darah, menambah gairah, dan menjaga berat badan [10].

Rendahnya frekuensi kawin pada kelompok kontrol positif diduga berkaitan dengan dosis yang digunakan tidak sesuai untuk hewan uji, atau adanya perbedaan respon tubuh masing-masing mencit. Minuman berenergi mengandung pemanis buatan natrium siklamat, guarana, taurin, variasi bentuk gingseng, dan kafein yang tinggi atau bahkan jumlahnya tidak diketahui memiliki dampak negatif seperti gejala kelainan jantung, gangguan emosi, gangguan perilaku, obesitas, dan diabetes [11].

Hasil penelitian pada (Gambar 2) menunjukkan tidak adanya perbedaan berat badan pada kelompok kontrol negatif maupun perlakuan menggunakan rebusan air akar ilalang, yaitu rata-rata 31 gram. Ini berbeda dengan kelompok perlakuan kontrol positif, dimana terjadi peningkatan berat badan menjadi 33 gram, karena adanya kandungan glukosa yang sangat tinggi melebihi kebutuhan pada minuman berenergi. Konsumsi glukosa yang tinggi tanpa diimbangi dengan aktivitas akan memicu kegemukan dan peningkatan kadar glukosa darah.

Hewan uji yang diberi perlakuan minuman berenergi yaitu seperti diam serta tidak aktif bergerak menanggapi respon betina pada saat disatukan dalam kandang. Selain itu minuman berenergi juga mengandung kandungan yang berkarbonat dan tidak berkarbonat yang dapat merusak organ ginjal. Sedangkan pada perlakuan menggunakan perlakuan aquades, air rebusan akar ilalang $9 \mathrm{~mL}$ dan air rebusan akar ilalang $18 \mathrm{~mL}$ yang rata-rata berat badannya hanya 31 gram setelah diberi perlakuan selama 7 hari dikarenakan perlakuan menggunakan aquades, air rebusan akar ilalang tidak terdapat pemanis buatan seperti natrium siklamat.

\section{SIMPULAN DAN SARAN}

Berdasarkan hasil penelitian ini dapat disimpulkan bahwa: rebusan air akar ilalang meningkatkan stamina mencit jantan secara nyata pada taraf signifikasi 5\%. Hasil uji lanjut menunjukkan tidak ada perlakuan yang paling berpengaruh tetapi pada kelompok perlakuan 2 menggunakan air rebusan akar ilalang $18 \mathrm{~mL} / \mathrm{kg}$ BB paling direkomendasikan karena memiliki rata-rata frekuensi kawin tertinggi 47,50 kali dibandingkan dengan tiga kelompok perlakuan lainnya. Penelitian ini perlu dilanjutkan dengan mengamati kemungkinan munculnya efek samping, dengan melakukan uji keamanan. Selain itu perlu dilakukan uji lanjut menggunakan ekstrak akar ilalang sehingga dapat diperoleh informasi khasiatnya yang lebih terukur. 


\section{UCAPAN TERIMAKASIH}

Penulis mengucapkan terimakasih kepada Allah Yang Maha Esa, Orang tua dan keluarga yang telah memberikan dukungan penuh terhadap studi saya. Penulis juga mengucapkan terima kasih kepada Pembimbing 1 Bapak Dr. Yohanes Edy Gunawan, M.Si., Pembimbing 2 Bapak Adventus panda, S.Si., M.Si., yang telah membimbing, mengarahkan, dan mengajarkan segala hal sehingga penelitian ini dapat selesai. Penulis juga mengucapkan terima kasih kepada para kerabat kuliah (MK) dan pendidikan biologi kelas A angkatan 2015 yang juga memberikan dukungan kepada saya.

\section{REFERENSI}

[1] Haneda, F. dan S. Utari. 2010. Pemanfaatan Etnobotani dari Hutan Tropis Bengkulu Sebagai Pestisida Nabati. Bogor. IPB. JMHT 17 (3) : 143-147.

[2] Nurrani, L. (2013). Pemanfaatan Tradisional Tumbuhan Alam Berkhasiat Obat Oleh Masyarakat Di Sekitar Cagar Alam Tangale. Vol 3. No 1. BPK. Manado.

[3] Soerjani M. 1970. Ilalang \{Imperata cylindrica (L.) Beauv.), Pattern of Growt as Related to its Problem Control. Biotrop Bulletin No. 1, 88.

[4] Rahayu, M., S. Sunarti, D. Sulistiarini dan S. Prawiroatmodjo. 2006. Pemanfaatan tumbuhan obat secara tradisional oleh masyarakat lokal di Pulau Wawonii, Sulawesi Tenggara.

[5] Jumiarni, W, O; dan Komalasari, O. 2017. Eksplorasi jenis dan pemanfaatan tumbuhan obat pada Masyarakat suku muna di permukiman kota wuna.

[6] Kinho, J., Arini, D.I.D., Tabba, S., Kama, H., Kafiar, Y., Shabri, H. dan Karundeng, M. 2011. Tanaman Obat Tradisional Sulawesi Utara Jilid I. Manado: Balai Penelitian Kehutanan Manado.

[7] Nuning, Rahmawati dan Ikayanti, M.S. 2011. Efek Afrosidiak Ramuan Cabe Jawa (Piper retrrofracum L), Pegangan (Centella asiatica), dan Temu Lawak (Curcuma domestica) Terhadap Libido Mencit Jantan. Jawa Tengah: Balai Besar Penelitian dan Pengembangan Tanaman Obat dan Obat Tradisional Tawamangu.

[8] Seniwaty, Raihanah, Ika Kusuma Nugraheni, Dewi Umaningrum. 2009. Skrining Fitokimia Dari Alang-Alang (Imperata cylindrica L. Beauv) dan Lidah Ular (Hedyotis corymbosa L. Lamk). Banjarbaru : Universitas Lambung Mangkurat.

[9] Davis, J.M., Zhao, Z., Stock, H.S., Mehl, K.A., Buggy, J., and Hand, G.A., 2003, Central Nervous System Effects of Caffeine and Adenosine on Fatigue, American Journal Physiology Regulatory Integrative and Comparative Physiology, 284 (2), 399-404.

[10] Widodo A., 2013. Stress pada Penderita Diabetes Mellitus Tipe 2 dalam Melaksanakan Program Diet di klinik Penyakit Dalam RSUP. Dr. Kariadi Semarang. Medica Hospitalia. vol. 1(1), pp. 53-5.
[11] Widodo A., 2013. Stress pada Penderita Diabetes Mellitus Tipe 2 dalam Melaksanakan Program Diet di klinik Penyakit Dalam RSUP. Dr. Kariadi Semarang. Medica Hospitalia. vol. 1(1), pp. 53-5. 